\title{
Pengaruh Suhu Pengeringan Terhadap Aktivitas Antioksidan Dan Karakteristik Teh Celup Herbal Daun Mint (Mentha piperita L.)
}

\section{Effect of Drying Temperature On Antioxidant Activity And Characteristics Herbal Teabag of Mint Leaves (Mentha piperita L.)}

\author{
Asti Sucianti ${ }^{1}$, Ni Made Yusa ${ }^{1 *}$, I Made Sugitha ${ }^{1}$ \\ Program Studi Teknologi Pangan, Fakultas Teknologi Pertanian, Universitas Udayana \\ Kampus Bukit Jimbaran, Badung-Bali \\ *Penulis korespondensi: Ni Made Yusa, Email: madeyusa@unud.ac.id
}

\begin{abstract}
This study aims to find out the effect of drying temperature on antioxidant activity and characteristics of mint leaf herbal tea bags and to know the drying temperature that can produce herbal tea bags mint leaves with the highest antioxidant activity and best characteristics. The design used in this study is a Complete Randomized Design with drying temperature treatment consisting of 5 levels of 5 levels namely $50^{\circ} \mathrm{C}, 55^{\circ} \mathrm{C}, 60^{\circ} \mathrm{C}, 65^{\circ} \mathrm{C}$, and $70^{\circ} \mathrm{C}$. This study was repeated three times so that 15 experimental units were obtained. The data obtained were analyzed with fingerprints and if the treatment had any real effect continued with Duncan's test. Parameters tested in this study include water content, yield, total phenol levels, total flavonoid levels, antioxidant and $\mathrm{IC}_{50}$ activity, and sensory characteristics. The results showed herbal teabag mint leaves with a drying temperature of $50^{\circ} \mathrm{C}$ is the best treatment based on water content value of 7,52\%, yield $14,16 \%$, total phenol $6,50 \mathrm{mgGAE} / \mathrm{g}$, total flavonoids 5,15 $\mathrm{mgGAE} / \mathrm{g}$, antioxidant activity 54,55\% with IC50 value of $86,18 \mathrm{ppm}$, yellow color, very characteristic aroma of mint leaf tea and preferred, fresh mint flavor, and overall acceptance preferred.
\end{abstract}

Keywords: antioxidant, drying temperature, tea bags, mint leaves

\section{PENDAHULUAN}

Teh herbal merupakan produk minuman teh dalam bentuk tunggal atau campuran herbal lainnya yang memiliki khasiat yang beragam dalam membantu pengobatan suatu penyakit tergantung jenis bahan herbal yang digunakan (Daroini, 2006). Teh herbal dapat dibuat dari bahan dedaunan, biji-bijian, bunga, dan akar dari tanaman. Salah satu daun yang dapat dibuat menjadi teh herbal adalah Mentha piperita $\mathrm{L}$ atau dikenal sebagai daun mint.

Daun mint (Mentha piperita L.) merupakan tanaman herbal yang memiliki kandungan antioksidan yang tinggi, bersifat antimikroba, antitumor, dan antialergenic. Daun mint banyak dimanfaatkan dalam industri farmasi, rokok, dan makanan contohnya antara lain untuk pembuatan pasta gigi, minyak angin, balsam, kembang gula, jeli, dan salad (Hadipoentyanti, 2012). Berdasarkan penggunaannya sebagai bumbu dapat digunakan untuk bumbu daging, ikan, dan sup. Selain itu juga daun mint banyak digunakan sebagai minuman seperti minuman bersoda, es buah, es krim, dan teh herbal. Kandungan minyak esensial pada daun mint seperti mentol, mentone canvone, methyl acetate, dan peperitone berperan dalam menghambat pertumbuhan mikroba, antioksidan, merangsang sekresi asam empedu, memperbaiki laju pertumbuhan dan mengurangi produksi amonia (Maulina, 2012). 
Pembuatan teh celup herbal daun mint dapat dilakukan dengan cara pengeringan. Metode pengeringan yang digunakan dalam penelitian ini yaitu pengeringan secara non konvensional yaitu dengan menggunakan metode oven. Pengeringan oven memiliki keunggulan yaitu suhu pengeringan yang mudah diatur. Faktor-faktor yang berpengaruh dalam proses pengeringan antara lain luas permukaan, kecepatan udara, kelembapan udara $(\mathrm{RH})$, tekanan atm \& vakum, waktu dan yang terakhir adalah suhu, semakin tinggi suhu pengeringan maka semakin cepat terjadi penguapan (Hartuti, 1997).

Dengan melakukan pengeringan, rendemen pada daun mint berkurang dan proses ini juga berpengaruh terhadap komponen bioaktif yang terdapat pada simplisia tersebut. Pengeringan yang tepat akan menghasilkan mutu simplisia yang tahan lama dalam proses penyimpanan serta tidak merubah kandungan bahan aktif yang terdapat dalam simplisia (Manoi,2006). SNI 2836:2013 tentang teh kering dalam kemasan persyaratan rendemen pada teh menyatakan bahwa standar maksimum rendemen adalah $30 \%$, dengan demikian keamanan dan kondisi bahan aktif pada simplisia dapat terjaga dalam waktu yang lama.

Berdasarkan hasil penelitian Danik (2018), pengolahan teh kombinasi daun tin dan daun mint dengan variasi lama pengeringan pada suhu $50^{\circ} \mathrm{C}$ dengan lama pengeringan 120 menit menghasilkan teh terbaik dengan aktivitas antioksidan tertinggi yaitu $81,652 \%$. Menurut Santi (2018), suhu yang digunakan pada pembuatan teh herbal daun kenikir dan daun mint untuk aktivitas antioksidan tertinggi pada suhu $55^{\circ} \mathrm{C}$ dengan lama pengeringan 120 menit yaitu $67,58 \%$. Semakin tinggi suhu pengeringan maka akan semakin rendah aktivitas antioksidannya dan dapat merusak antioksidan pada sampel tersebut.

Produk teh dalam bentuk kemasan dapat lebih mudah dikonsumsi oleh masyarakat. Selain itu, dapat dijadikan peluang usaha bagi produsen sehingga dibuat produk teh celup. Teh celup merupakan bubuk teh yang dikemas menggunakan kantong berbahan kertas atau nilon atau bahan yang memenui standar dengan menggunakan tali atau tanpa tali sehingga memudahkan dalam penyeduhan (Anomius, 2014). Penelitian mengenai pengaruh suhu pengeringan terhadap teh celup herbal daun mint belum dilakukan sebelumnya. Berdasarkan hal tersebut, maka perlu dilakukan penelitian mengenai pengaruh suhu pengeringan terhadap aktivitas antioksidan dan karakteristik teh celup herbal daun mint.

\section{METODE PENELITIAN}

\section{Bahan dan Alat}

Bahan yang digunakan dalam penelitian ini adalah daun mint yang diperoleh dari areal perkebunan Desa Kembang Merta, Kecamatan Baturiti, Kabupaten Tabanan, Bali dan bahanbahan kimia seperti DPPH(1,1-Diphenyl-2-picryl Hidrazil) (Himedia), reagen Folin-Ciocalteu (merck), Methanol PA 100\% (merck), standar asam galat (merck), $\mathrm{Na} 2 \mathrm{CO} 3$ (Natrium Karbonat) (merck), AlCl3 (Aluminium Klorida), standar kuersetin (sigma).

Alat-alat yang digunakan pada penelitian ini yaitu corong kaca, oven (ESCO Isotherm), blender 
(Vienta), ayakan 40 mesh, timbangan analitik (Shimadzu), spatula, alumunium foil, gelas ukur, erlenmeyer, botol gelap, gelas beaker, spektrofotometer (Biochrom), kufet kaca, pipet volume, pipet tetes, pipet mikro, vortex, tabung reaksi, tabung sentrifuge, sentrifuge (Danamon IEC), labu ukur $5 \mathrm{ml}$, dan labu ukur $100 \mathrm{ml}$.

\section{Pelaksanaan Penelitian}

Pelaksanaan penelitian meliputi tahapan yaitu:

\section{Pembuatan Bubuk Teh Herbal Daun Mint}

Pembuatan bubuk teh herbal daun mint diawali dengan proses pemetikan mulai dari daun yang muda dan segar yaitu satu hingga empat tingkatan di bawah pucuk daun dan disortasi dengan kondisi baik dan tidak terkena hama. Proses selanjutnya pencucian daun untuk menghilangkan kotoran yang menempel menggunakan air mengalir dan ditiriskan. Selanjutnya dilakukan proses pengeringan menggunakan oven dengan suhu $50^{\circ} \mathrm{C}, 55^{\circ} \mathrm{C}, 60^{\circ} \mathrm{C}$, $65^{\circ} \mathrm{C}$, dan $70^{\circ} \mathrm{C}$ selama 2 jam agar kadar air daun mint dapat berkurang. Setelah kering dilakukan proses penghancuran menggunakan blender. Setelah hancur selanjutnya dilakukan pengayakan menggunakan ayakan 40 mesh.

\section{Pembuatan Teh Celup Herbal Daun Mint}

Pembuatan teh celup diawali dengan menimbang bubuk teh herbal daun mint dengan berat masing - masing kantong teh sebanyak 2 gram, kemudian dilakukan pengemasan dengan kantong teh berukuran 5,2 x 5,8 cm dengan jenis kantong teh merk tea.

\section{HASIL DAN PEMBAHASAN}

Nilai rata - rata analisis kadar air dan rendemen dari teh celup herbal daun mint dapat dilihat pada Tabel 1. Nilai rata - rata analisis total fenol, total flavonoid, dan aktivitas antioksidan dari teh celup herbal daun mint dapat dilihat pada Tabel 2.

\section{Kadar Air}

Hasil analisis ragam menunjukkan bahwa suhu pengeringan berpengaruh sangat nyata $(\mathrm{P}<0,01)$ terhadap kadar air teh celup herbal daun mint. Berdasarkan Tabel 1 dapat dilihat bahwa kadar air teh celup herbal daun mint berkisar Antara 5,47\% sampai dengan 7,52\%. Nilai ratarata kadar air terendah terdapat pada perlakuan S5 (suhu pengeringan $70^{\circ} \mathrm{C}$ ) yaitu $5,47 \%$., sedangkan nilai rata-rata kadar air tertinggi terdapat pada perlakuan $\mathrm{S} 1$ (suhu pengeringan $50^{\circ} \mathrm{C}$ ) yaitu $7,52 \%$.

Hal ini disebabkan karena penguapan air akibat dari meningkatnya suhu pengeringan. Semakin tinggi suhu pengeringan menyebabkan penguapan air yang terdapat pada teh celup herbal daun mint semakin tinggi sehingga kadar air yang terdapat pada teh celup herbal daun mint semakin rendah. Hal ini didukung oleh pernyataan Widjanarko (2012), laju penguapan disamping dipengaruhi oleh tingkat kelembaban juga dipengaruhi oleh suhu di sekitar bahan yang dikeringkan. Berdasarkan SNI kadar air untuk produk teh maksimal $8 \%$. Ini menandakan bahwa produk teh celup herbal daun mint tidak melampaui batas maksimal kadar air SNI. Kadar air dalam bahan pangan dapat menentukan kesegaran dan daya awet bahan pangan. Apabila kadar air dalam 
teh kering cukup banyak maka akan menyebabkan teh menjadi lembab dan mudah rusak (Herawati dan Agus, 2007).

Tabel 1. Nilai rata-rata kadar air dan rendemen dari teh celup herbal daun mint

\begin{tabular}{ccc}
\hline $\begin{array}{c}\text { Perlakuan suhu pengeringan } \\
\left({ }^{\circ} \mathrm{C}\right)\end{array}$ & $\begin{array}{c}\text { Kadar Air } \\
(\% \mathrm{bb})\end{array}$ & $\begin{array}{c}\text { Rendemen } \\
(\% \mathrm{bb})\end{array}$ \\
\hline $\mathrm{S} 1\left(50^{\circ} \mathrm{C}\right)$ & $7,52 \pm 0,27^{\mathrm{a}}$ & $14,16 \pm 0,57^{\mathrm{a}}$ \\
$\mathrm{S} 2\left(55^{\circ} \mathrm{C}\right)$ & $7,12 \pm 0,12^{\mathrm{a}}$ & $11,94 \pm 0,49^{\mathrm{b}}$ \\
$\mathrm{S} 3\left(60^{\circ} \mathrm{C}\right)$ & $6,53 \pm 0,31^{\mathrm{b}}$ & $10,78 \pm 0,89^{\mathrm{c}}$ \\
$\mathrm{S} 4\left(65^{\circ} \mathrm{C}\right)$ & $5,67 \pm 0,18^{\mathrm{c}}$ & $10,08 \pm 0,68^{\mathrm{d}}$ \\
$\mathrm{S} 5\left(70^{\circ} \mathrm{C}\right)$ & $5,47 \pm 0,13^{\mathrm{c}}$ & $9,46 \pm 0,34^{\mathrm{d}}$ \\
\hline
\end{tabular}

Keterangan: huruf yang berbeda di belakang nilai rata-rata pada setiap kolom yang sama menunjukan perbedaan yang sangat nyata $(\mathrm{P}<0,01)$.

Tabel 2. Nilai rata-rata kadar total fenol, kadar total flavonoid, dan aktivitas antioksidan dari teh celup herbal daun mint

\begin{tabular}{cccc}
\hline $\begin{array}{c}\text { Perlakuan suhu } \\
\text { pengeringan }\left({ }^{\circ} \mathrm{C}\right)\end{array}$ & $\begin{array}{c}\text { Total Fenol } \\
(\mathrm{mgGAE} / \mathrm{g})\end{array}$ & $\begin{array}{c}\text { Total Flavonoid } \\
(\mathrm{mgQE} / \mathrm{g})\end{array}$ & Aktivitas Antioksidan (\%) \\
\hline $\mathrm{S} 1\left(50^{\circ} \mathrm{C}\right)$ & $6,50 \pm 0,08^{\mathrm{a}}$ & $5,15 \pm 0,09^{\mathrm{a}}$ & $54,55 \pm 3,11^{\mathrm{a}}$ \\
$\mathrm{S} 2\left(55^{\circ} \mathrm{C}\right)$ & $6,27 \pm 0,02^{\mathrm{b}}$ & $4,87 \pm 0,09^{\mathrm{b}}$ & $44,63 \pm 0,62^{\mathrm{b}}$ \\
$\mathrm{S} 3\left(60^{\circ} \mathrm{C}\right)$ & $6,16 \pm 0,04^{\mathrm{b}}$ & $4,60 \pm 0,06^{\mathrm{c}}$ & $43,85 \pm 2,07^{\mathrm{b}}$ \\
$\mathrm{S} 4\left(65^{\circ} \mathrm{C}\right)$ & $5,97 \pm 0,07^{\mathrm{c}}$ & $4,29 \pm 0,04^{\mathrm{d}}$ & $34,67 \pm 0,23^{\mathrm{c}}$ \\
$\mathrm{S} 5\left(70^{\circ} \mathrm{C}\right)$ & $5,79 \pm 0,12^{\mathrm{d}}$ & $4,00 \pm 0,05^{\mathrm{e}}$ & $27,94 \pm 1,25^{\mathrm{d}}$ \\
\hline
\end{tabular}

Keterangan: huruf yang berbeda di belakang nilai rata-rata pada setiap kolom yang sama menunjukan perbedaan yang sangat nyata $(\mathrm{P}<0,01)$.

\section{Rendemen}

Hasil analisis ragam menunjukkan bahwa suhu pengeringan berpengaruh sangat nyata $(\mathrm{P}<0,01)$ terhadap rendemen teh celup herbal daun mint. Berdasarkan Tabel 1 dapat dilihat bahwa rendemen teh celup herbal daun mint berkisar Antara 9,46\% sampai dengan $14,16 \%$. Nilai ratarata rendemen terendah terdapat pada perlakuan S5 (suhu pengeringan $70^{\circ} \mathrm{C}$ ) yaitu 9,46\%., sedangkan nilai rata-rata rendemen tertinggi terdapat pada perlakuan $\mathrm{S} 1$ (suhu pengeringan $50^{\circ} \mathrm{C}$ ) yaitu $14,16 \%$.
Hal ini disebabkan karena semakin tinggi suhu pengeringan maka rendemen serbuk daun mint semakin rendah. Menurut pendapat Wahyuni (2015), menyatakan bahwa nilai rendemen suatu produk akan semakin menurun jika suhu pengeringan semakin tinggi. Menurut pendapat Winarno (1992), menyatakan bahwa proses pengeringan menyebabkan kandungan air selama proses pengolahan berkurang sehingga menyebabkan penurunan rendemen. Menurut Rahmawati (2004), menyatakan bahwa semakin kecil kadar air suatu bahan akan berakibat pada semakin kecilnya bobot air yang terkandung dalam 
bahan tersebut. Air yang terkandung dalam suatu bahan merupakan komponen utama yang mempengaruhi bobot bahan, apabila air dihilangkan maka bahan akan lebih ringan sehingga mempengaruhi rendemen produk akhir.

\section{Total Fenol}

Hasil analisis ragam menunjukkan bahwa suhu pengeringan berpengaruh sangat nyata $(\mathrm{P}<0,01)$ terhadap total fenol teh celup herbal daun mint. Berdasarkan Tabel 2 dapat dilihat bahwa total fenol teh celup herbal daun mint berkisar antara 5,79 mgGAE/g sampai dengan 6,50 mgGAE/g. Nilai rata-rata total fenol terendah terdapat pada perlakuan S5 (suhu pengeringan $70^{\circ} \mathrm{C}$ ) yaitu $5,79 \mathrm{mgGAE} / \mathrm{g}$, sedangkan nilai ratarata total fenol tertinggi terdapat pada perlakuan $\mathrm{S} 1$ (suhu pengeringan $50^{\circ} \mathrm{C}$ ) yaitu $6,50 \mathrm{mgGAE} / \mathrm{g}$.

Hal ini disebabkan karena suhu pengeringan yang semakin tinggi dapat menurunkan senyawa fenolik secara cepat dikarenakan bahan bersentuhan langsung dengan uap panas, kadar total fenol semakin meningkat seiring dengan penurunan suhu pengeringan, karena daun mint dalam penelitian ini mengandung senyawa fenol sebesar 6,50 mgGAE/g yang berfungsi sebagai antioksidan utama seperti limonene, cineole, menthone, menthol, dan pulegone (Alankar, 2009). Kadar fenol berhubungan erat dengan aktivitas antioksidan sehingga semakin meningkat kadar fenol, maka aktivitas antioksidan akan semakin meningkat. Hal ini sesuai dengan pernyataan Husna (2013), bahwa komponen bioaktif aktivitas antioksidan mempunyai sifat tidak tahan panas. Sehingga ketika suatu sampel di keringkan dalam keadaan panas maka akan menurunkan nilai aktivitas antioksidan dan senyawa fenoliknya.

\section{Total Flavonoid}

Hasil analisis ragam menunjukkan bahwa suhu pengeringan berpengaruh sangat nyata $(\mathrm{P}<0,01)$ terhadap total flavonoid teh celup herbal daun mint. Berdasarkan Tabel 2 dapat dilihat bahwa total flavonoid teh celup herbal daun mint berkisar antara 4,00 mgQE/g sampai dengan 5,15 $\mathrm{mgQE} / \mathrm{g}$. Nilai rata-rata total flavonoid terendah terdapat pada perlakuan S5 (suhu pengeringan $70^{\circ} \mathrm{C}$ ) yaitu $4,00 \mathrm{mgQE} / \mathrm{g}$, sedangkan nilai ratarata total flavonoid tertinggi terdapat pada perlakuan $\mathrm{S} 1$ (suhu pengeringan $50^{\circ} \mathrm{C}$ ) yaitu 5,15 $\mathrm{mgQE} / \mathrm{g}$.

Hal ini disebabkan karena pada senyawa fenolik turun sehingga akan membuat senyawa flavonoid juga mengalami hal yang sama, flavonoid merupakan bagian dari antioksidan yang dipengaruhi oleh fenolik. kadar total flavonoid meningkat seiring dengan menurunnya suhu pengeringan pada teh celup herbal daun mint, karena daun mint dalam penelitian ini mengandung senyawa flavonoid sebesar 5,15 mgQE/g yang bertindak sebagai antioksidan utama seperti menthoside, isorhoifolin, eugenol dan thymol (Alankar, 2009). Hasil penelitian Santi (2018) tentang pengaruh suhu pengeringan dan perbandingan daun kenikir dan daun mint terhadap karakteristik teh celup herbal campuran yang menyimpulkan bahwa semakin meningkat suhu pengeringan akan memberikan pengaruh penurunan pada flavonoid. 


\section{Aktivitas Antioksidan dan IC50}

Hasil analisis ragam menunjukkan bahwa suhu pengeringan berpengaruh sangat nyata $(\mathrm{P}<0,01)$ terhadap aktivitas antioksidan teh celup herbal daun mint. Berdasarkan Tabel 2 dapat dilihat bahwa aktivitas antioksidan teh celup herbal daun mint berkisar antara 27,94\% sampai dengan $54,55 \%$. Nilai rata-rata aktivitas antioksidan terendah terdapat pada perlakuan S5 (suhu pengeringan $70^{\circ} \mathrm{C}$ ) yaitu $27,94 \%$, sedangkan nilai rata-rata aktivitas Antioksidan tertinggi terdapat pada perlakuan $\mathrm{S} 1$ (suhu pengeringan $50^{\circ} \mathrm{C}$ ) yaitu $54,55 \%$.

Hal ini disebabkan karena suhu pengeringan yang digunakan dan berpengaruh pada hasil aktivitas antioksidan teh celup herbal daun mint. Menurut Salunkhe dan Kadam dalam penelitian Muawanah (2012) aktivitas antioksidan dipengaruhi oleh senyawa fenol dan flavonoid yang terkandung dalam teh celup herbal daun mint. Semakin tinggi kandungan fenol dan flavonoid maka akan semakin tinggi aktivitas antioksidan. Daun mint memiliki komponen fenol seperti limonene, cineole, menthone, menthol, dan pulegone yang bertindak sebagai antioksidan dan dapat mencegah proses oksidasi dengan menutup atau menangkap radikal bebas. (Alankar, 2009).

Berdasarkan hasil analisis aktivitas antioksidan, suhu pengeringan $50^{\circ} \mathrm{C}$ memiliki persentase aktivitas antioksidan tertinggi sehingga dipilih untuk penentuan $\mathrm{IC}_{50}$. Nilai $\mathrm{IC}_{50}$ yang diperoleh sebesar 86,18 ppm. Semakin kecil nilai $\mathrm{IC}_{50}$ maka aktivitas antioksidan lebih tinggi dalam menangkal radikal bebas. Teh celup herbal daun mint $\mathrm{S} 1$ (suhu pengeringan $50^{\circ} \mathrm{C}$ ) dikategorikan antioksidan kuat. Hal ini berdasarkan pernyataan Blois (1958) nilai $\mathrm{IC}_{50}$ kurang dari 50 ppm dikategorikan antioksidan sangat kuat, $\mathrm{IC}_{50}$ yang berkisar antara 50-100 ppm dikategorikan antioksidan kuat, $\mathrm{IC}_{50}$ yang berkisar antara 100-150 dikategorikan antioksidan sedang, dan nilai $\mathrm{IC}_{50}$ yang berkisar antara 150-200 ppm dikategorikan antioksidan lemah.

\section{Karakteristik Sensoris}

Karakteristik sensoris teh celup herbal daun mint dilakukan dengan uji rangking dan hedonik. uji rangking dilakukan terhadap warna, aroma, dan rasa sedangkan uji hedonik dilakukan terhadap aroma dan penerimaan keseluruhan (Adawiyah, 2009). Penyeduhan teh celup herbal daun mint mengikuti prosedur SNI $3753: 2014$ mengenai teh hitam celup. Penyeduhan dilakukan dengan memasukan 1 kantong teh dengan berat sebanyak 2 gram kedalam gelas, kemudian ditambahkan air panas sebanyak $200 \mathrm{ml}$ lalu dibiarkan selama 5 menit sambil kantong digerakan keatas dan kebawah. Kantong teh dikeluarkan dan larutan teh dibiarkan dingin sampai suhu kamar $\left(20^{\circ} \mathrm{C}-25^{\circ} \mathrm{C}\right)$. Nilai rata - rata rangking terhadap warna, aroma, dan rasa dapat dilihat pada Tabel 3. Nilai rata - rata hedonik terhadap aroma dan penerimaan keseluruhan dapat dilihat pada Tabel 4.

\section{Warna}

Hasil analisis ragam menunjukkan bahwa suhu pengeringan berpengaruh sangat nyata $(P<0,01)$ terhadap warna seduhan teh celup herbal daun mint dengan uji rangking. Berdasarkan Tabel 3 dapat dilihat bahwa nilai rata-rata rangking berkisar antara 1,44 (kuning) sampai dengan 4,28 (coklat kemerahan). Nilai rata-rata rangking 
panelis terhadap warna teh celup herbal daun mint terendah diperoleh pada perlakuan S5 (suhu pengeringan $70^{\circ} \mathrm{C}$ ) yaitu dengan kriteria coklat kemerahan dan berbeda tidak nyata dengan perlakuan $\mathrm{S} 4$ (suhu pengeringan $65^{\circ} \mathrm{C}$ ). Sedangkan nilai rata-rata tertinggi diperoleh pada perlakuan $\mathrm{S} 1$ (suhu pengeringan $50^{\circ} \mathrm{C}$ ) yaitu dengan kriteria kuning.

Warna air seduhan teh celup herbal daun mint dengan suhu pengeringan $70^{\circ} \mathrm{C}$ memiliki warna yang lebih gelap dibandingkan dengan warna air seduhan teh celup herbal daun mint dengan suhu pengeringan $50^{\circ} \mathrm{C}$. Hal ini disebabkan karena semakin naik suhu pengeringan maka warna teh celup herbal daun mint semakin memudar, warna seduhan teh celup herbal daun mint yang terbentuk dari warna kuning menjadi coklat kemerahan. Memudarnya warna teh celup herbal daun mint disebabkan karena terjadinya degradasi pigmen-pigmen yang ada pada daun mint, suhu pengeringan yang terlalu tinggi menyebabkan terjadinya degradasi klorofil menjadi feofitin sehingga menghasilkan teh yang berwarna lebih gelap dan pigmen flavonoida yang menghasilkan warna kuning pada teh celup herbal daun mint. Menurut Lubis (2008) suhu pengeringan yang terlalu tinggi dapat menyebabkan pigmen-pigmen pada bahan mengalami oksidasi sehingga memucatkan pigmen. Suhu pengeringan yang terlalu tinggi menyebabkan terjadinya perubahan warna bahan serta terjadinya penurunan mutu bahan (Lidiasari dkk., 2006).

Tabel 3. Nilai rata - rata ranking terhadap warna, aroma, dan rasa teh celup herbal daun mint

\begin{tabular}{cccc}
\hline $\begin{array}{c}\text { Perlakuan suhu } \\
\text { pengeringan }\left({ }^{\circ} \mathrm{C}\right)\end{array}$ & Warna & Aroma & Rasa \\
\hline $\mathrm{S} 1\left(50^{\circ} \mathrm{C}\right)$ & $1,44 \pm 0,91^{\mathrm{c}}$ & $1,68 \pm 0,9^{\mathrm{d}}$ & $2,36 \pm 1,41^{\mathrm{c}}$ \\
$\mathrm{S} 2\left(55^{\circ} \mathrm{C}\right)$ & $3,20 \pm 1,15^{\mathrm{b}}$ & $2,44 \pm 0,65^{\mathrm{c}}$ & $3,16 \pm 1,10^{\mathrm{b}}$ \\
$\mathrm{S} 3\left(60^{\circ} \mathrm{C}\right)$ & $3,56 \pm 0,91^{\mathrm{b}}$ & $2,84 \pm 0,68^{\mathrm{b}}$ & $3,20 \pm 0,40^{\mathrm{b}}$ \\
$\mathrm{S} 4\left(65^{\circ} \mathrm{C}\right)$ & $4,08 \pm 0,76^{\mathrm{a}}$ & $3,12 \pm 0,53^{\mathrm{b}}$ & $2,48 \pm 1,36^{\mathrm{c}}$ \\
$\mathrm{S} 5\left(70^{\circ} \mathrm{C}\right)$ & $4,28 \pm 0,84^{\mathrm{a}}$ & $3,68 \pm 0,69^{\mathrm{a}}$ & $3,96 \pm 0,8^{\mathrm{a}}$ \\
\hline
\end{tabular}

Keterangan: huruf yang berbeda di belakang nilai rata-rata pada setiap kolom yang sama menunjukan perbedaan yang sangat nyata $(\mathrm{P}<0,01)$.

Tabel 4. Nilai rata - rata hedonik aroma dan penerimaan keseluruhan teh celup herbal daun mint

\begin{tabular}{ccc}
\hline Perlakuan suhu pengeringan $\left({ }^{\circ} \mathrm{C}\right)$ & Aroma & $\begin{array}{c}\text { Penerimaan } \\
\text { Keseluruhan }\end{array}$ \\
\hline S1 $\left(50^{\circ} \mathrm{C}\right)$ & $5,68 \pm 0,9^{\mathrm{a}}$ & $5,56 \pm 0,77^{\mathrm{a}}$ \\
$\mathrm{S} 2\left(55^{\circ} \mathrm{C}\right)$ & $4,92 \pm 0,86^{\mathrm{b}}$ & $5,12 \pm 0,6^{\mathrm{b}}$ \\
$\mathrm{S} 3\left(60^{\circ} \mathrm{C}\right)$ & $5,00 \pm 0,91^{\mathrm{b}}$ & $5,00 \pm 0,86^{\mathrm{b}}$ \\
$\mathrm{S} 4\left(65^{\circ} \mathrm{C}\right)$ & $4,84 \pm 0,94^{\mathrm{b}}$ & $4,68 \pm 0,75^{\mathrm{b}}$ \\
$\mathrm{S} 5\left(70^{\circ} \mathrm{C}\right)$ & $4,08 \pm 1,18^{\mathrm{c}}$ & $4,12 \pm 0,73^{\mathrm{c}}$ \\
\hline
\end{tabular}

Keterangan: huruf yang berbeda di belakang nilai rata-rata pada setiap kolom yang sama menunjukan perbedaan yang sangat nyata $(\mathrm{P}<0,01)$. 


\section{Aroma}

Hasil analisis ragam menunjukkan bahwa suhu pengeringan berpengaruh sangat nyata $(\mathrm{P}<0,01)$ terhadap aroma seduhan teh celup herbal daun mint dengan uji rangking. Berdasarkan Tabel 3 dapat dilihat bahwa nilai rata-rata rangking berkisar antara 1,68 (sangat khas teh daun mint) sampai dengan 3,68 (agak khas teh daun mint). Nilai rata-rata rangking panelis terhadap aroma teh celup herbal daun mint terendah diperoleh pada perlakuan S5 (suhu pengeringan $70^{\circ} \mathrm{C}$ ) yaitu dengan kriteria agak khas teh daun mint. Sedangkan nilai tertinggi diperoleh pada perlakuan $\mathrm{S} 1$ (suhu pengeringan $50^{\circ} \mathrm{C}$ ) yaitu dengan kriteria sangat khas teh daun mint.

Teh celup herbal daun mint dengan perlakuan $\mathrm{S} 1$ (suhu pengeringan $50^{\circ} \mathrm{C}$ ) memiliki nilai rangking aroma tertinggi karena aroma khas teh celup herbal daun mint yang dapat dirasakan ketika proses penyeduhan. Teh celup herbal daun mint dengan perlakuan S5 (suhu pengeringan $70^{\circ} \mathrm{C}$ ) memiliki nilai rangking aroma terendah karena dengan adanya peningkatan suhu pengeringan dapat mengurangi aroma khas seduhan teh celup herbal daun mint. Daun mint memiliki komponen aroma seperti menthone, isomenthone, menthofuran, carvone, linalool dan piperitone oxide (Verma dkk., 2010). Sehingga dengan semakin meningkatnya suhu pengeringan maka aroma khas teh celup herbal daun mint akan semakin berkurang, menurut Hadi (2011) aroma pada teh disebabkan karena adanya senyawa aromatik yang mudah menguap, dan komponen kimia teh herbal seperti karbohidrat, protein, gugus reduksi gula saat diseduh, serta adanya oksidasi senyawa polifenol dan turunannya seperti tanin.

Kandungan daun mint juga mengandung menthol dimana menthol merupakan senyawa aromatis yang berbau tajam dan bersifat mudah menguap (Abbas, 2005). Disamping itu, penelitian Ghassani (2009) menyatakan bahwa aroma dari daun mint efektif dapat meningkatkan performansi memori jangka pendek pada panelis.

Hasil analisis ragam menunjukkan bahwa suhu pengeringan berpengaruh sangat nyata $(\mathrm{P}<0,01)$ terhadap aroma seduhan teh celup herbal daun mint dengan uji hedonik. Berdasarkan Tabel 4 dapat dilihat bahwa nilai rata-rata sensoris oleh panelis berkisar antara 4,08 (agak tidak suka) sampai dengan 5,68 (suka). Nilai rata-rata kesukaan panelis terhadap aroma teh celup herbal daun mint terendah diperoleh pada perlakuan S5 (suhu pengeringan $70^{\circ} \mathrm{C}$ ) yaitu dengan kriteria agak tidak suka, sedangkan nilai rata-rata tertinggi diperoleh pada perlakuan S1 (suhu pengeringan $50^{\circ} \mathrm{C}$ ) yaitu dengan kriteria suka. Aroma khas teh celup herbal daun mint menghasilkan aroma mentol. Perlakuan suhu pengeringan yang semakin meningkat membuat aroma mentol pada teh celup herbal daun mint semakin menurun sehingga semakin tidak disukai oleh panelis.

\section{Rasa}

Hasil analisis ragam menunjukkan bahwa suhu pengeringan berpengaruh sangat nyata $(\mathrm{P}<0,01)$ terhadap rasa seduhan teh celup herbal daun mint dengan uji rangking. Berdasarkan Tabel 3 dapat dilihat bahwa nilai rata-rata rangking berkisar antara 2,36 (sangat mint segar) sampai dengan 3,96 (tidak mint segar). Nilai rata-rata 
rangking panelis terhadap rasa teh celup herbal daun mint terendah diperoleh pada perlakuan S5 (suhu pengeringan $70^{\circ} \mathrm{C}$ ) yaitu dengan kriteria tidak mint segar, sedangkan nilai tertinggi diperoleh pada perlakuan S1 (suhu pengeringan $\left.50^{\circ} \mathrm{C}\right)$ yaitu dengan kriteria sangat mint segar dan berbeda tidak nyata dengan perlakuan S4 (suhu pengeringan $65^{\circ} \mathrm{C}$ ).

Semakin tinggi suhu pengeringan maka rasa teh celup herbal daun mint semakin berkurang, hal ini disebabkan oleh kandungan minyak atsiri berkurang selama proses pengeringan. Menurut Wijaya (2015), minyak atsiri dapat menguap pada suhu pengeringan yang terlalu tinggi. Rasa tidak pahit pada teh celup herbal daun mint berasal dari kandungan mentol sehingga memiliki cita rasa segar(minty).

\section{Penerimaan Keseluruhan}

Hasil analisis ragam menunjukkan bahwa perlakuan peningkatan suhu pengeringan berpengaruh sangat nyata $(\mathrm{P}<0,01)$ terhadap penerimaan keseluruhan seduhan teh celup herbal daun mint dengan uji hedonik. Berdasarkan Tabel 4 menunjukkan nilai rata-rata uji hedonik terhadap penerimaan keseluruhan teh celup herbal daun mint berkisar antara 4,12 (biasa) samapai dengan 5,56 (suka). Penerimaan keseluruhan teh celup herbal daun mint dipengaruhi oleh berbagai faktor seperti warna, aroma, dan rasa.

\section{KESIMPULAN DAN SARAN}

\section{Kesimpulan}

Berdasarkan hasil penelitian yang telah dilakukan dapat diambil kesimpulan yaitu Suhu pengeringan pada teh celup herbal daun mint berpengaruh sangat nyata $(\mathrm{P}<0,01)$ terhadap kadar air, rendemen, total fenol, flavonoid, aktivitas antioksidan, warna (rangking), aroma (rangking dan hedonik), rasa (rangking), dan penerimaan keseluruhan (hedonik). Pengeringan suhu $50^{\circ} \mathrm{C}$ menghasilkan teh celup herbal daun mint dengan aktivitas antioksidan tertinggi dan karakteristik terbaik yaitu kadar air 7,52\%, rendemen $14,16 \%$, total fenol 6,50 mgGAE/g, total flavonoid 5,15 $\mathrm{mgQE} / \mathrm{g}$, aktivitas antioksidan 54,55\% dengan nilai $\mathrm{IC}_{50}$ sebesar $86,18 \mathrm{ppm}$, warna kuning, aroma sangat khas teh daun mint dan disukai, rasa mint segar, dan penerimaan keseluruhan disukai.

\section{DAFTAR PUSTAKA}

Abbas, A. 2005. The yield and essential oil content of mint (Mentha ssp.) in Northern Ostrobothnia, Faculty of Science, Department of Biology, University of Oulu, Oulu university Press, Oulu, Finland, p. 16-41.

Adawiyah, D. 2009. Buku Ajar Evaluasi Sensoris Produk Pangan. Fakultas Teknologi Pertanian, IPB, Bogor.

Alankar, S. (2009). A review on peppermint oil. Asian Journal of Pharmaceutical and Clinical Research, 2(2), 27-33.

Anonimus. 2014. SNI 3753:2014. Teh Hitam Celup. Badan Standar Nasional, Jakarta.

Anonimus. 2016. SOP : The Hitam PT. Bali Cahaya Amerta. Bali Cahaya Amerta, Bali.

Blois, M.S. 1958. Antioxidant determinations by the use of a stable free radical. Nature, 181:11991200.

Doroni, O.S. 2016. Kajian Proses Pembuatan Teh Herbal Dari Campuran Teh Hijau (Camellia sinensis), Rimpang Bangle (Zingiber assumunar Roxb.) dan Daun Ceramai (Phyllanthus acidus (L). Skeels). Skripsi. Tidak dipublikasikan. Fakultas Teknologi Pertanian IPB, Bogor.

El Husna, N., M. Novita dan S. Rohaya. 2013. Kandungan antosianin dan aktivitas antioksidan ubi jalar ungu segar dan produk olahannya. Agritech, 33(3), 296-302.

Gardiner, P. 2000. Peppermint (Mentha piperita). The Center for Holistic Education and Research. Revised May 2, 1-22. 
Hadipoentyanti, E. 2012. Pedoman Teknis Mengenal Tanaman Mentha (Mentha Arvensis L.) Dan Budidayanya. Bogor: Balai Penelitian Tumbuhan Rempah Dan Obat.

Hartuti, N. dan R. M. Singga. 1997. Pengeringan Cabai. Balai Penelitian Tanaman Sayuran, Pusat Penelitian dan Pengembangan Hortikultura, Badan Penelitian dan Pengembangan Pertanian Bandung.

Herawati, H. dan N. Agus. 2007. Peningkatan Nilai Tambah Produk The Hijau Rakyat di Kecamatan Cikalong Wetan-Kabupaten Bandung. Jurnal Pengkajian dan Pengembangan. Teknologi Pertanian. 10(3):241-249.

Lidiasari, E., M.I, Syafutri dan F. Syaiful. 2006. Pengaruh perbedaan suhu pengeringan tepung tapai ubi kayu terhadap mutu fisik dan kimia yang dihasilkan. Jurnal Ilmu-Ilmu Pertanian Indonesia, 8(2), 141-146.

Lubis, I. H. 2008. Pengaruh lama dan suhu pengeringan terhadap mutu tepung pandan. Skripsi. Fakultas Pertanian. Universitas Sumatera Utara. Medan.

Manoi F. 2006. Pengaruh Cara Pengeringan Terhadap Mutu Simplisia Sambiloto. Bul. Littro17 (1) : 15.

Maulina, D. 2012. Teknik Budidaya Tanaman Rempah Dan Penyegar (Daun Mint). Universitas Syiah Kuala, Banda Aceh.

Muawanah, A., I. Djajanegara, A. Sa'duddin, \& D. Sukandar. 2012. Penggunaan bunga kecombrang (Etlingera Elatior) dalam proses formulasi permen jelly. Jurnal Kimia Valensi, 2(4).

Pendit PACD, E Zubaidah, dan FH Sriherfyna. 2016. Karekteristik Fisik Kimia dan Aktivitas Antibakteri Ekstrak Daun Belimbing Wuluh (Averrhoa bilimbi L.). Jurnal Pangan dan Agroindustri 4 (1): 400-409.

Pranowo, D. F. Wahyono. D.W. Harjanti. 2016. Efektifitas Rebusan Daun Kersen (Muntinga Calabura L.) Sebagai Antiseptik Puting Dalam Menurunkan Populasi Staphylococcus Aureus Dalam Susu Sapi. Prosiding Seminar Nasional Kebangkitan Peternakan. Universitas Diponegoro, Semarang.

Primadiati, R. 2002. Aromaterapi. Jakarta : PT. Gramedia Pustaka Utama.

Qiao, L, Y. Sun, R. Chen, Y. Fu, W. Zhang, X. Li, J. Chen, Y. Shen, X. Ye. 2014. Sonochemical effects on 14 flavonoids common in citrus: relation to stability. PLoS ONE 9(2):1-10.

Rahman, A., Riyanto dan Utari. 2006. Aktivitas Antioksidan, Kandungan Fenolat Total dan Kandungan Flavonoid Total Ekstrak Etil Asetat
Buah Mengkudu Serta Fraksi-Fraksinya. Majalah Farmasi Indonesia. 17:137-13.

Rofiah, D., \& T. Suryani. 2018. Aktivitas Antioksidan Dan Organoleptik Teh Kombinasi Daun Tin Dan Daun Mint Dengan Variasi Lama Pengeringan (Doctoral dissertation,Universitas Muhammadiyah Surakarta).

Rohdiana, D. 2007. Petunjuk Teknis Pengolahan Teh. Pusat Penelitian Teh dan Kina. Gambung.

Sakanaka, S., Y. Tachibana, Okada dan Yuki. 2003. Preparation and Antioxiant Properties Of Extracts of Japanese Persimo Leaf Tea (kakinocha-cha) food chemistry. 89.569-575.

Santi, K. B. 2018. Pengaruh Lama Pengeringan dan Perbandingan Daun Kenikir (Cosmos caudatus) dan Daun Mint (Mentha piperita L.) Terhadap Karakteristik Teh Celup Herbal Campuran (Doctoral dissertation, Fakultas Teknik Unpas).

Steel, R.G.D dan J.H. Torrie. 1993. Prinsip dan Prosedur Statistika Suatu Pendekatan Biometrik. Penerjemah B. Sumantri. PT. Gramedia Pustaka, Jakarta.

Sudarmadji, S., B. Haryono dan Suhardi. 1997. Prosedur Analisa Untuk Bahan Makanan dan Pertanian. Liberty, Yogyakarta.

Tjitrosoepomo, G. 2010. Taksonomi tumbuhan obatobatan. Gadjah Mada University Press.

Verma, R. S., L. Rahman., R. K., Verma, A., Chauhan, A.K., Yadav, \& A, Singh. 2010. Essential oil composition of menthol mint (Mentha arvensis) and peppermint (Mentha piperita) cultivars at different stages of plant growth from Kumaon region of Western Himalaya. Open Access Journal of Medicinal and Aromatic Plants, 1(1), 13-18.

Wahyunindiani DY, S Wijana, dan Sucipto. 2015. Pengaruh Perbedaan Suhu dan Waktu Pengeringan Terhadap Aktivitas Antioksidan Bubuk Daun Sirsak (Annona muricata L.). Jurnal Alumni Jurusan Teknologi Industri Pertanian. Fakultas Teknologi Pertanian. Universitas Brawijaya: Malang.

Waji, R.A. 2009. Flavonoid (Quercetin). Makalah Kimia Organik Bahan Alam. Fakultas Matematika dan Ilmu Pengetahuan Alam. Universitas Hasanuddin. Makassar.

Wijanarko, A. 2012." Hubungan anemia dengan pengetahuan gizi, konsumsi $\mathrm{Fe}$, Protein, Vitamin C, dan pola haid pada mahasiswa putri" dalam media gizi mikro Indonesia. Jurnal Balai Penelitian dan Pengembangan kesehatan.

Wijaya, C., A. Jayuska, \& A. H. Alimuddin. 2015. Peningkatan Rendemen Minyak Atsiri Daun Cengkeh (Syzygium aromaticum) dengan 
Metode Delignifikasi dan Fermentasi. Jurnal Kimia Khatulistiwa, 4(4).
Winarno FG. 1992. Kimia Pangan dan Gizi. PT. Gramedia Pustaka Utama: Jakarta. 